\title{
Literacy Culture in the Islamic Religious Education and the Development of Islam in Indonesia
}

\author{
Firdaus Wajdi \\ Program Studi Pendidikan Agama Islam, Fakultas Ilmu Sosial, Universitas Negeri Jakarta \\ firdaus.wajdi@unj.ac.id
}

Naskah diterima: 20 April 2020, direvisi:15 Juli 2020; disetujui: 17 Juli 2020

\begin{abstract}
Abstrak
Globalisasi telah memungkinkan pengembangan Islam di satu wilayah dengan bantuan gerakan global. Fenomena ini juga terjadi di Indonesia. Namun, apa yang tidak banyak kita pahami adalah bagaimana Ulama Turki telah berkontribusi untuk mengembangkan budaya literasi Islam untuk meningkatkan perkembangan Islam di Indonesia. Artikel ini berupaya mengidentifikasi Gerakan Nur Jamaat yang telah memanfaatkan globalisasi untuk membangun budaya literasi di kalangan Muslim Indonesia dan memperkenalkan karya-karya Bediuzzaman Said Nursi. Melalui penelitian yang cermat terhadap gerakan global ini, studi ini berupaya memahami bagaimana organisasi Muslim global mengambil keuntungan dari globalisasi dan apa tanggapan Muslim lokal terhadapnya. Ini adalah penelitian kualitatif dengan observasi, wawancara, serta penelitian kepustakaan sebagai alat pengumpulan data. Penelitian ini memuncak berupaya untuk memahami bagaimana globalisasi telah menjadi mekanisme yang positif dalam perkembangan organisasi Islam di Indonesia.
\end{abstract}

Kata Kunci: budaya literasi Islam, pendidikan Islam, Jamaat Nur.

\begin{abstract}
Globalization has enabled the development of Islam in one localized region with the help of global movements. What we do not much understand is how Turkish Ulama have contributed to develop Islamic literacy culture to enhance the development of Islam in Indonesia. This paper identified Jamaat Nur Movement who have utilized globalization to establish literacy culture among Indonesian Muslims and introduced the works of Bediuzzaman Said Nursi. This study supports the argument that religion plays significant role in the society. Globalization drives this trend further. Through careful study of this global movement, this study seeks to understand how a global Muslim organization took advantage from globalization and what are the local Muslims responses to it. This is a qualitative research with observation, interview, as well as library research as tools of data collection. The research keen to understand how globalization has become a tool for development of Islamic organization in Indonesia.
\end{abstract}

Keywords: Islamic literacy culture, Islamic education, Jamaat Nur.

\section{Introduction}

Indonesia is a meeting point of scholars who spread Islam from various countries and with colorful backgrounds. Many academic works explain that there is much evidence of the identity of cultural diversity and background in the development of Islam in Indonesia (Drakeley, 2005; Kersten, 2018; Pringle, 2012; Saat, 2018). Islamic scholars have played a 
role since the early entry of Islam into Indonesia. Likewise, scholars from India who contributed to further developments related to the entry of Islam into the archipelago. Meanwhile, Egypt became one of the countries where many Indonesians Ulama and students studied. Likewise, with Yaman, especially the Hadralmaut region which is well-known in the series of teachers of habib students in Indonesia (Fox, 2004).

The relationship established between Muslims from Indonesia and Muslims from various countries then played a pivotal role in the development of Islam in Indonesia. One very clear picture can be seen through the development of Islamic organizations and Islamic education institutions in Indonesia. It can be said that Islamic organizations as well as Islamic education institutions in Indonesia get a significant influence in terms of academic and ideological encounters between Indonesian Muslims and Muslims from various overseas regions (Azmil Tayeb, 2018; Rumadi \& Lunnon, 2015; Saleh, 2001). Therefore, it becomes instinctive when Indonesia is colored by various models of education and organizations that have a variety of religious orientations. Starting from the modernist model to the traditionalist, everything mingled in Indonesia, bringing culture from the country of origin and playing its role in the development of Islam in the world's largest Muslim majority country.

Among the many countries whose ulama play a very significant role, it can be said that Saudi Arabia, Yemen and Egypt have been overheard quite often in the discussion of the development of Islam in Indonesia. The role of those scholars from the country has also been mentioned in various studies (Dijk et al., 2016; Fogg, 2015; Setyaningrum, 2015). Saudi Arabia has always been a place of reference for Indonesian Ulema when it explores Islamic sciences and Islamic pilgrimage. Islamic tradition and high-level clerical education often ascribed to anyone who has studied and even taught in a country where Islam originated. Later, Saudi Arabia is also known in the study of Salafism which integrated through religious movements and Islamic educational institutions such as schools and universities. Meanwhile, the Hadhramaut, which in the modern time located in the administration of the territory of the Republic of Yemen, in Indonesia has played a large role in the development of Islam. The habaib (the descendants of Prophet Muhammad PBUH) disgrace that in the cities like Jakarta and surrounding areas took part in establishing the Majelis Dhikr and Sholawat (The assembly of dhikr and sholawat) be ascribed to the Muslim scholars descent of Hadhramaut. Their role in promoting Islam to young people in Indonesia is undeniably significant. Then, Egypt has been identified as one of the countries whose Ulama played an 
important role in the development of Indonesia, particularly through the education, more specifically by the existence of Al Azhar University which became one of the ideal universities of many Indonesian students while continuing to pursue higher education. The description of Al-Azhar University in Egypt with its Ulama and alumni has become a consistent destination for Indonesian students. Currently, Al Azhar University alumni in Indonesia are significant, and many of them are Ulama who play an important role in the development of Islam in Indonesia.

Considering the many facts above, interestingly, there is little academic information that discusses the role of the Turkish Ulema in Indonesia, especially in the contemporary period. Relations between Turkey and Indonesia were recorded more in classical history when the Islamic Kingdom of Samudera Pasai requested the help of the Ottoman Turks in dealing with colonialism in the archipelago (Permana, 2019). This gives the impression that Turkey has no longer plays a role in the development of Islam in this contemporary era. This is certainly contrary to the fact that between Indonesia and Turkey share many common situation in terms of Muslim majority country, ethnicity, education, and even politics as has been studied by many academics (Geri, 2019; Parsons, 1997; Schneier, 2016). Thus, this article seeks to give a small contribution in introducing the role of Turkish Muslims in the development of Islam and Islamic education in Indonesia. In particular, this article also seeks to uncover the literacy culture of Islam brought and introduced by Turkish Muslims in Indonesia. This is an interesting point of view of the development of Islam according to the writer, because this literacy culture is not much chosen as an approach to the development of religion in Indonesia. Moreover, Indonesian people in general, and therefore also Indonesian Muslims in general, still have a level of reading ability that is an important part of literacy that is still below average according to the low according to the PISA Report in 2018 (OECD, 2018).

This study aims to complete the profile of Ulama who carry out dakwah and play role in the development of Islam in Indonesia. The Ulama spread Islam with the belief that dakwah was part of the obligation that must be carried out in the teachings of Islam and the dawah was not limited by time and space as had been exemplified by the Messenger of Allah PBUH and also the companions of the Prophet known as the Shalafussalih. This is crucial enough to get the latest picture in the development of Islam in Indonesia. Indonesia is a country with the largest Muslim majority population in the world in one country. Activities undertaken by Muslims in Indonesia in various fields are believed to be able to give an 
overview of Muslims globally (Simandjuntak, 2018). This, for example, can be shown by the many studies on religious moderation in Indonesia that have received enough attention from the global world (Wahyudi, 2019).

This research is a study of religion and Muslim diversity with the Social Sciences approach which takes a sample in the field of non-formal Islamic Religious Education. Therefore, besides observing the activities and role of the Turkish Muslim in the context of the development of Islam in Indonesia, this research also utilizes social theories as its theoretical framework. The author observes that the activities of Turkish Muslims in Indonesia has been made possible due to the globalization. Globalization can be understood as a process towards increasingly stronger interrelations and dependencies between one part of the world and one another, where events and developments in one region affect most other regions. One often argued that globalization was the one that allows the development of Islam to spread all over the world. This could be true. However, it also needs to be understood that Islam is a religion that is a source of motivation for its adherents. The nature of this case, as stated by Meuleman, Islam has played an important role in the globalization process since the very beginning. Meuleman even stressed that this is not a coincidence for Islam, but rather it is the fundamental attributes. Islam has totally influenced the political, economic and cultural life among societies (J. H. Meuleman, 2002).

Globalization as a theoretical framework can be justified by the fact that this theory has been so widely used by academics in discussing religion in various elements such as, basic doctrines, spirituality, economics and politics. There is no doubt that globalization is one of the important theories. Meuleman For example, recognizing that globalization is one of the fundamental issues today (J. Meuleman, 2005). In his book, Islam in the Era of Globalization: Muslim Attitudes towards Modernity and Identity, he describes how globalization relates to aspects of Muslim life, not only within their local communities, but also in the midst of the Diaspora communities.

Meanwhile, Ali Muhammadi in Islam Encountering Globalization says that there are many aspects that need to be discussed about how the Muslim countries to face globalization and how to consider the response of Western country against Islam. It is very important with regard to the development of Islam in the Western state. At present the development of Islam in Western countries such as in the USA and Europe is progressing very impetuously. In America, Islam developed quite considerably in the midst of the community of inmates who were looking for identity. Meanwhile Europe has long been a destination country for 
immigrants, some of whom are Muslims. Assimilation is inevitable in an increasingly globalized world (Mohammadi, 2002).

Furthermore, globalization and Islam are interrelated in various joints and elements of Islam, including economics, politics, education and so on. In the financial sector, Askari in Globalization and Islamic Finance: Convergence, Prospects and Challenges explains how globalization really affects how Muslims practice their religion, in particular, with finances that are around the globe cannot be limited by space and time so that from the outset of the financial aspects necessarily linked with globalization. Thus, Muslims have their own challenges to be able to identify the benefits of globalization for implementation Islam for Muslims, both in developed and developing countries (Askari et al., 2011). The economy in general will indeed be linked to globalization. Rudnyckyj for example, writing about economic relations in Islam and globalization in Spiritual economies: Islam, globalization, and the afterlife of development (Rudnyckyj, 2010).

Not only the above elements, globalization also affects the basic conception, shape, and political side of religiosity. Professor Peter Beyer in Religion in the Context of Globalization: Essays on Concepts, Forms, and Political Implication explains how the debate between religion and globalization that has been going on for years and is important to understand because it relates to various things, including conception, form and the political implications of religion (Beyer, 2013). Another work that explain the link between religion, globalization, and politics is a Religious Pluralism, Globalization, and World Politics written by (Banchoff, 2008). Furthermore, related to politics, globalization also then influences and relates to state policies and their relationship with nationalism and religion. Kosebalaban gives example of how Islam as the religion of the majority in Turkey later associated with nationalism and at the same time also affect Turkey's foreign policy because the context of globalization (Kosebalaban, 2011). Even in this article, the author will explain the impact of globalization and religious practices among Turkish Muslims who are not formal government actors, but representations of non-governmental organizations (NGOs) or civil society that are not spared from the dynamics of globalization and their practices with practice diversity. Not only in his own country, but also has grown global in other countries.

So, clearly globalization is one theory in which it can be used to analyze the study of social science as shown from the previous studies. This includes the connection between religion (Islam) and globalization which is already widely used by researchers and academics. This theory is established and therefore can be used in understanding how a 
person's religiosity can change with the influence of globalization. Globalization has denied the existence of geographical boundaries with advancements in the field of communication and cheap costs to carry out travel between countries. If in the past religious leaders (Ulama) could only teach religious knowledge in the mushalla of a village or in a class of a pesantren. At the moment, when the time and space limits can be said to be almost completely lost, an $u s t a d z$ can broadcast Islamic lectures through social media platforms from Indonesia and then having dialogue with members of the Diaspora community across the globe. Globalization with religious features has made it possible for many things that were previously unimaginable, including in terms religious practices.

The hypothesis that is built in this paper is that globalization is believed to play an important role in enabling Turkish Muslims to contribute to the development of the Muslim community in Indonesia and to introduce a culture of Turkish as seen in the various works above. However, what is interesting is how it all happened and how the response of local Muslims to the role of the Turkish cleric. It is the one that will be described in this paper.

\section{Research methods}

The method used in this study is a qualitative research (Bryman, 2008) that tries to understand how globalization influence the behavior of religious scholars in Turkey who then contribute on the development of Islam in Indonesia. The formulation of the problem to be examined in this study is how do Turkish Muslims play a role in the development of Islam in Indonesia? To answer this problem, researcher combines observation, interviews, and literature study as tools of data collection. Observations were carried out at the boarding (dershane) of Yayasan Nur Semesta (Nur Semesta Foundation), located in Ciputat, South Tangerang, Banten Province. Observations carried out alongside a weekly lecture that discuss and the Magnum Opus of Bediuzzaman Said Nursi. This weekly gathering is the best moment to get to know the members of the Thulabunnur congregation better and understand how the literacy culture process runs systematically. In addition to the moment of weekly study, researchers also have the opportunity to carry out observations on activities that are not routinely carried out weekly, but less frequently. This activity is an intensive reading activity carried out in Puncak, Bogor, West Java. Meanwhile, interviews were conducted to confirm things that were still unclear during the observation process. The interview was carried out by asking permission from the leadership of the Nur Semesta Foundation who was considered to have the best understanding of the role played by Turkish Muslims in promoting Islamic education in Indonesia. Then, to complement the study of Turkish 
Muslims in Indonesia with this globalization perspective, researcher also of course complete it with literature studies. Journal articles, academic books, and news contained in news portals and social media platforms such as Instagram and Facebook become valuable study material in this study. The data from this literature review, although it may be assessed as secondary data, are proven to be able to clarify the various kinds of information needed to better understand the role of Turkish Muslims in Indonesia.

The research that produced this article began in 2013 based on the researchers' interest in the Turkish Muslims movement which has not been widely documented in Indonesia and then this research was culminated in the March-April 2020. This was an ethnographic research that I did among the three Turkish Muslim organizations in Indonesia. My interaction started with the Suleymaniyah and then later with the Thulabunnur and the Gulen Affiliated movements. Hopefully, this paper can be valued as a contribution to understanding the big picture of Islam in Indonesia with the role of Turkish Muslim in Indonesia.

\section{Results and Discussion}

The relationship of modern interactions between Indonesian Muslims and Turkish Muslims in an organized and systematic manner can be traced since the late 1990s and early 2000s. The period of time that is a time when Muslim Turkey made little effort dakwah globally. Not only Muslims in Indonesia, however, Turkish Muslims also do a lot of preaching movements in countries of the former Soviet Union in Central Asia such as Kazakhstan, Kyrgyzstan, Tajikistan, Turkmenistan, and Uzbekistan. These countries have a close cultural relationship with Turkish Muslims, so it is only natural for Turkish Muslims to choose their place of preaching there. Turkish Muslims develop (Islamic) education, which is carried out both formally and informally (Ozdalga, 1999; Turam, 2004; Yilmaz, 2018).

But then, Turkish Muslims also saw great dakwah opportunities in other countries, such as Indonesia, which has a very large Muslim population. This certainly provides an enormous opportunity to develop Islamic education in a Muslim-majority country. So, since around the beginning of the third millennium, Turkish Muslims have expanded their dakwah wing to Indonesia. They started with a business scheme which then continued with an education scheme. One of the characteristics brought by Turkish Muslims is the modern and luxurious impression for most Indonesian Muslims. Therefore, it did not take long for Indonesian Muslims, especially those from the middle class to receive dakwah and services provided by Turkish Muslims in Indonesia. 
There are at least three large groups of Turkish Muslims who play their role in promoting Islamic education in Indonesia. Each group has quite different characteristics, but it can be said that as a whole complements each other in the service context (hizmet) in Islam and the field of education (of Islam) in Indonesia. The first group was a group inspired by Fethullah Gulen, who came to be known as the Gulen affiliated Movements. The second group is students from the charismatic Ulema, Syeikh Suleyman Hilmi Tunahan, known as Murshid Kamil in the Naqshbandiyah Tariqah. Meanwhile, the third group were students from Bediuzzaman Said Nursi, known as Thullabunnur. Related to the topic and focus of this paper as a study of the development of Islamic literacy culture for the development of Islam in Indonesia by Turkish Muslims, the authors limit the discussion to only the third group, represented by Nur Semesta Foundation who is very active in improving this literacy culture.

\section{Understanding the Nur Semesta Foundation}

Yayasan Nur Semesta (The Nur Semesta Foundation) is an Indonesian based institution that houses hizmet or religious service conducted by Thullabunnur (the students who study and read the Risalah Nur). This institution is very devoted and consistent in developing a culture of religious literacy through the introduction and study of the Risalah Nur. Located in a a building in one of the beautiful housing complex, the Nur Semesta Foundation is like an oasis for students who want to read the wisdom listed in Bediuzzaman Said Nursi's series of works. Quite often dershane of the Nur Semesta Foundation hosts a gathering for fellow of Thullabunnur accross the globe. The guests were the resource persons in learning Risalah Nur in the dershane of Nur Semesta Foundation.

As is the case with other organizations in the digital era today, besides being active offline, the Nur Semesta Foundation is also active through online channels. This foundation has Facebook account, Youtube Channel, Instagram, and also the WhatsApp group. Even when the Covid-19 outbreak hits Indonesia and there were suggestions for psychical distancing or social distancing, the Nur Semesta Foundation also held online recitals. This clearly addresses moderate attitudes and culture in responding to globalization and its features that can help the implementation of religious activities.

Generally, there are three main activities are the most significant undertaken by Nur Semesta Foundation which is the non-formal Islamic education through boarding system (dershane), teaching of works of Bediuzzaman Said Nursi, and growing the literacy culture through translation and publication of the works of Beduzzaman Said Nursi. This activity is 
closely related to the conception of acceptance of globalization and has also proven to be consistently successful in fostering a culture of reading and increasing the literacy of religions from Turkish Ulama works in Indonesia, especially the monumental work of Bediuzzaman Said Nursi, Risalah Nur. The following will be discussed in detail.

\section{a. Study of Risalah Nur}

Study of Risalah Nur is a routine activity carried out by Thulabunnur. It has been the culture to read the works of Said Nursi. Therefore, one of the indications to know thullabunnur is by looking at the Risalah Nur collection at his residence. If, there is a collection of red-covered books typical of Risalah Nur, it is almost certain that the owner of the house, or the person who lives in that place is one of the Thullabunnur. Although Risalah of Nur have been translated and published in various languages, cover design and use of color is quite typical and identified quickly that the collection of these books is a collection of works of Bediuzzaman Said Nursi, teacher of Thullabunnur.

Although, Risalah Nur are quite similar to the book of Tafsir and can be read at any time, but usually, the Thulabbunur community has an agreed time to gather and read and discuss together this Nur Minutes book. In Ciputat village, the Nur Semesta Foundation usually conducts a joint reading session on Thursday night Friday after the evening until around 22:00. The recitation is usually led by a cleric who is more commonly called "abi" which is a Turkish word. The equivalent to brother in English or Akh in Arabic language. Abi who leads the recitation is usually a senior student in the Thullabunnur community because of course it is required to be able to lead and also explain the content of the study.

The recitation usually starts by the leader who would read the part of Risalah Nur while the other participants listen. After reading, the part will be explained. Then it goes on. The study leader can also ask participants to read parts of the Risalah Nur in turn. Usually a few paragraphs and then explained by the study leader. And so on. Participants and study leaders can also conduct question and answer session related to the material being discussed or read. Many interesting things in the discussion of the Risalah Nur because Bediuzzaman Said $\mathrm{Nu}$ provided quite a lot of scientific explanations in the presentation of Islamic propositions and materials. This is quite suitable with academics such as lecturers and university students. Though of course all people gladly accepted to study and read the works of Bediuzzaman Said Nursi. Even in Turkey itself, recitation is usually held and adjusted to the group of worshipers based on their profession. 
As mentioned above that sometimes the Risalah Nur recitation is also led by a cleric from Turkey or other countries. Usually, the cleric or abi visits countries where Thulabunnur has been able to hold recitation of Risalah of Nur. The arrival of the abi provided an important point. The existence of the dershande or recitation of Risalah Nur by the Thulabunnur is not a local only community. However, it is a Thulabunnur community among Thulabunnur communities in various countries globally. Of course, this community originated from Turkey and was indeed started by Turkish Muslims, however, this community has been present in various countries and is quite consistent in studying the work of Bediuzzaman Said Nursi. Arrival abi from Turkey or abroad also make Thulabunnur Indonesia is proud to be visited directly by the $a b i$ of the various countries.

In addition to the Risalah Nur review, which is carried out on a regular basis once a week, it is also sometimes conducted irregularly. There is a reading activity known as a reading program (okumak). Usually, this program is carried out for about one week in a special place which can also be made for mind refreshing. For example, the researcher was invited to attend a reading program at a villa in the Puncak area, West Java. A very conducive place for intensive reading. Various works of Bediuzaman Said Nursi, both original books and translations, can be read in the program. This activity is quite similar to the short Islamic boarding school activities that are common in the Muslim community in Indonesia, known as pesantren kilat.

\section{b. Dershane (Boarding) of Thulabunnur}

Nur Semesta Foundation made the boarding for students who want to learn the works Bediuzzaman Sadi Nursi. The boarding is known as Dershane. Ders means learning, while hane means room or house. Thus, dershane can be interpreted as a place to study. Things to be learned is the religion of Islam in general, and the works of Bediuzzaman Said Nursi.

The dershane is built and managed by an ustadz or usually called $a b i$ which means brother or akh. The dershane is equipped with prayer rooms in congregation, santri rooms, libraries and guest rooms. Different from the usual pesantren in Indonesia, where Islamic boarding schools usually occupy a fairly large building complex consisting of dormitories, classrooms and mosques, the Thulabunnur dershane is sometimes quite simple and not necessarily large. The dormitory in which the researcher visited in the Ciputat area, for example, is a two-story house in a housing complex. Although small, the dershane is the center of activities of Thulabunnur. Usually, although not always, santri living in the drshane are university students. This is suitable with the characteristics of dershane which 
is located around the campus or university, considering that Bediuzzaman Said Nursi's work is very suitable to be read by academics.

Starting from a dormitory for female students in the Ciputat area, the Nur Semesta Foundation has now fostered dorms in various places established by Thulabunnur who are committed to teaching the Treatise of Nur and contributing to the development of Islam through the introduction of literacy by Turkish Ulema, Bediuzzaman Said Nursi. The dershane is meant to be a center of study and also a place for full- time students. Later, they are expected to become abi who can distribute the works of Bediuzzaman Said Nursi.

There are indications that part of the boarding house under the management of the Nur Semesta Foundation was initially to receive assistance from a generous Turkish Muslim who sponsored the founding of dershane in Indonesia. Not only funds, but also human resources were also bought from abroad (Turkey) or Turkish Muslims who were already familiar with the works of Bediuzzaman Said Nursi. The ustadz or abi who became the head of this dershane were Turkish Muslims who had indeed intended to carry out hizmet (service) in the field of religion. They even sometimes endow themselves and the time they have is only to take care of the dershane and preach to teach Islam and introduce the works of Bediuzzaman Said Nursi.

However, this mechanism does not become the only mechanism establishment dershane because apparently there is also the founder of the initiative from the Thulabunnur themselves. They usually have been Thulabunnur long enough and then they are moved to change their houses or buildings to become dershane to study Islam and the works of Bediuzzaman Said Nursi. The combination of these two methods of establishment is showing significant results at the moment dershane in Indonesia is quite widespread.

\section{c. Translation and Publication}

The Nur Semesta Foundation, through a supporting institution, the Risalah Nur Press, implemented a translation program and then published the works of Bediuzzaman Said Nursi. This publishing process begins with the translation process first. Senior Santri and Foundation administrators who were considered to have a good understanding of the works of Bediuzzaman Said Nursi translated parts of the work diligently and systematically. Then, the translation is reviewed before publication.

The next process is the book publishing process carried out by the Risalah Nur Press which is also located in Ciputat. Quite a number of translated books from the works of 
Bediuzzaman Said Nursi have been published. The following is a list of books that researchers found listed in the ISBN National Library of the Republic of Indonesia catalog:

\begin{tabular}{|c|c|c|}
\hline No & Title & ISBN \\
\hline 1 & $\begin{array}{l}\text { Biografi Badiuzzaman Said Nursi berdasarkan tuturannya dan } \\
\text { tulisan para muridnya [Badiuzzaman Said Nursi's biography is } \\
\text { based on his speech and the writings of his students] }\end{array}$ & $978-602-73813-9-1$ \\
\hline 2 & $\begin{array}{l}\text { Cahaya iman dari bilik tahanan [Light of faith from the prison } \\
\text { room] }\end{array}$ & $978-602-73813-8-4$ \\
\hline 3 & Tuntunan generasi muda [Guidance of the younger generation] & $978-602-73813-7-7$ \\
\hline 4 & Al-Maktubat [Al-Maktubat] & $978-602-73813-6-0$ \\
\hline 5 & $\begin{array}{l}\text { Risalah ana \& thabi'ah: mengenal ego, menyangkal filsafat } \\
\text { naturalism [Minutes of ana \& thabi'ah: recognize ego, deny } \\
\text { philosophy of naturalism] }\end{array}$ & $978-602-73813-4-6$ \\
\hline 6 & Risalah ikhlas \& ukhuwah [Minutes of sincere \& ukhuwah] & $978-602-73813-3-9$ \\
\hline 7 & $\begin{array}{l}\text { Misteri puasa, hemat, dan syukur [The mystery of fasting, } \\
\text { thrifty, and gratitude] }\end{array}$ & $978-602-73813-2-2$ \\
\hline 8 & $\begin{array}{l}\text { Risalah Mi'raj: urgensi hakikat, hikmah dan buahnya [Mi'raj } \\
\text { Minutes: the urgency of the nature, wisdom and fruit] }\end{array}$ & $978-602-73813-1-5$ \\
\hline 9 & $\begin{array}{l}\text { Sunnah Nabi SAW: pedoman hidup muslim sejati [Sunnah of } \\
\text { the Prophet SAW: guidelines for true Muslim life] }\end{array}$ & $978-602-73813-0-8$ \\
\hline 10 & Risalah kebangkitan [Minutes of awakening] & $978-602-70284-9-4$ \\
\hline 11 & Iman kunci kesempurnaan [Faith is the key to perfection] & $978-602-70284-8-7$ \\
\hline 12 & $\begin{array}{l}\text { Nasihat spiritual: mengokohkan akidah menggairahkan ibadah } \\
\text { [Spiritual advice: strengthen faith and worship] }\end{array}$ & $978-602-70284-7-0$ \\
\hline 13 & $\begin{array}{l}\text { Mukjizat Al-Qur'an: ditinjau dari } 40 \text { aspek kemukjizatan } \\
\text { [Miracles of the Qur'an: in terms of } 40 \text { aspects of miracles] }\end{array}$ & $978-602-70284-6-3$ \\
\hline 14 & $\begin{array}{l}\text { Terapi Maknawi dengan Resep Qur'ani [Meaningful Therapy } \\
\text { with Qur'ani Recipe] }\end{array}$ & $978-602-70284-5-6$ \\
\hline 15 & $\begin{array}{l}\text { Kumpulan mukjizat Nabi Muhammad Saw [A collection of } \\
\text { miracles of the Prophet Muhammad] }\end{array}$ & 978-602-70284-4-9 \\
\hline
\end{tabular}




\begin{tabular}{|l|l|l|}
16 & $\begin{array}{l}\text { Khutbah syamiyah: manifesto kebangkitan umat Islam } \\
\text { [Sermon Syamiyah: Manifesto of the Resurrection of } \\
\text { Muslims] }\end{array}$ & $978-602-70284-3-2$ \\
\hline 17 & Tuntunan bagi perempuan [Guidance for women] & $978-602-70284-2-5$ \\
\hline 18 & Tuntunan generasi muda [Guidance of the younger generation] & $978-602-70284-1-8$ \\
\hline 19 & $\begin{array}{l}\text { Al-Lama'at: membumikan inspirasi illahi [Al- Lama'at: ground } \\
\text { divine inspiration] }\end{array}$ & $978-602-70284-0-1$ \\
\hline
\end{tabular}

Table no. 1

List of translated books that written by Badiuzzaman Said Nursi

As seen from the list of publications above, the Risalah Nur Press, which is part of the Nur Semesta Foundation, publish mainly small books that are light and easy for the younger generation. The younger generation seems to be the target audience that the Nur Semesta Foundation to educate them as generation of Muslims who are good in their Islam by knowing religion and also the works of Bediuzzaman Said Nursi. However, not only the younger generation, the general public was also given a sufficient portion of attention in which the Risalah Nur Press also published large books such as Al Lama'at. So, that they could become guidelines that could be read by all groups, including also being read in the format of recitation weekly routine.

The Nur Semesta Foundation and The Risalah Nur Press use social media to sell and distribute books that have been published. Facebook, Instagram, and WhatsApp are very popular applications in Indonesia and are therefore also used proportionally to distribute and sell these books. This is quite successful considering that today's society is so connected to social media. The author once ordered a book and everything can be done remotely. Ordered via WhatsApp, and payment made by transfer and delivery via courier. The Nur Semesta Foundation is like many others, once understanding the concept of an increasingly globalized world and finding the best way to benefit from globalization.

In addition to the general pattern of sales and distribution described above, the Nur Semesta Foundation and Nur Press Minutes are also active in the promotion of books by Bediuzzaman Said Nursi. The method of promotion that is often done is to take part in exhibitions of books both on a local scale such as on campus/ universities or on a national scale such as the Islamic Book Fair which is usually held once a year. Through these 
moments, the Nur Semesta Foundation introduce the works of Bediuzzaman Said Nursi, the Nur Semesta Foundation to Indonesian Muslim.

Nur Semesta Foundation also held launching a book and a book discussion involving national Ulama or national writers. For example, thenational writer Habiburrahman El Shirazy and the national Ustadaz of Ustadaz Abdul Somad. Both have a role to introduce Turkish culture in Indonesia. Habiburrahman El Shirazy, for example, is a famous novel writer whose work has been adapted into a feature film. One of Habiburrahman El Shirazy's novels has a Turkish background entitled Api Tauhid. By collaborating with national writers, the introduction of the work of Turkish Ulama, Bediuzzaman Said Nursi has also become more easily accepted by the Muslim community in Indonesia. At the very least, Muslim in Indonesia was not only introduced to novels and works of Turkish fiction, but also to Islamic works by Bediuzzaman Said Nursi, a well-known and respected cleric from Turkey.

Thus, Turkish Muslim in Indonesia has played a role in non-formal Islamic education by building a culture of literacy through deshane, recitation, and publication of books by the Great Ulama of Turkey, Bediuzzaman Said Nursi. Globalization in this case provides support in the form of a Turkish Muslim community that helps the founding of dershane and helps prepare human resources in the form of ustadz or abi who teach in Indonesia. Indonesia is the ideal place for propaganda because of the number of Muslims it is very significant and a lot of things that can be implemented here. This is in accordance with the thesis of Peter G. Mandaville and Hakan Yavuz, who stated that the ability of the scholars to develop Islamic teachings because they were able to find opportunities in these locations (Hasan, 2009; Yavuz, 2003).

Researcher also found indications that the Nur Semesta Foundation make an effort to understand local conditions and then adapt, things in the context of the science of sciences social referred to as glocalization. A concept introduced by Roland Robertson and Victor Roudometof (Robertson, 1995; Roudometof, 2003). The term glocalization first emerged in the 1980s when the farmers in Japan using a variety of different techniques from various parts of the world to find the best technique can be used locally. So, glocalization can also be understood as a global technique with a series of local adaptations. In further developments terms glocalization is developed by Ronald Robertson. According Glocalization is a phenomenon that indicates that local is part of a component of globalization. In later developments this is also used in the social field where people refer to cultural and social changes related to globalization. 
Giulianotti and Robertson explain that there are four types of locality, the first being Relativization. Where social actors try to maintain the old culture of old practices and the meaning of names in the new environment. The second accommodation in which social actors trying to absorb how pragmatic practices related to other cultures in an effort to maintain key elements of culture that word before. Third Hybridization is when an actor menu synthesis of the phenomenon of local culture creates hybrid tactics. Fourth, transformation when social actors agree with the practice of the new culture. In relation to the Thullabunnur pilgrims have carried out a glocalization process that focuses on accommodation where there is a process to absorb pragmatic ways of practices related to culture (Islam) in Indonesia as an effort to safeguard key elements of Turkish (Islamic in) culture. This is, for instance, evident from the usage of terms and methods, but the culture get customized Muslim community in Indonesia (Giulianotti \& Robertson, 2007).

\section{Conclusion}

This paper aims to understand how the role of Turkish Muslims in the development of Islam in Indonesia in a contemporary context. This study shows that the role of Turkish Muslims in Indonesia is inseparable from their ability to use the network of globalization and their ability to carry out the process of glocalization as part of good adaptation. With both of them, they are more easily accepted in Indonesia. Currently Indonesia has benefited from the presence of Turkish Muslims in Indonesia were spread and foster a culture of literacy in Islam through the study and publishing of rich literature of Bediuzzaman Said Nursi, the famous scholar from Turkey, who have inspired a lot the Islamic world.

\section{Bibliography}

Askari, H., Iqbal, Z., \& Mirakhor, A. (2011). Globalization and Islamic Finance: Convergence, Prospects and Challenges. Wiley.

Azmil Tayeb. (2018). Islamic education in Indonesia and Malaysia: shaping minds, saving souls.

Banchoff, T. F. (2008). Religious Pluralism, Globalization, and World Politics. Oxford University Press.

Beyer, P. (2013). Religion in the Context of Globalization : Essays on Concept, Form, and Political Implication. Taylor and Francis.

Bryman, A. (2008). Social Research Methods (Issue Book, Whole). Oxford University Press.

Dijk, C. van, Kaptein, N. J. G., \& Suharto. (2016). Islam, politics and change the Indonesian experience after the fall of Suharto.

Drakeley, S. (2005). The history of Indonesia. Greenwood Press. 
Fogg, K. W. (Kevin). (2015). Hamka's Doctoral Address at Al-Azhar: the Influence of Muhammad Abduh in Indonesia. Muhammadiyah University Yogyakarta.

Fox, J. J. (2004). Currents in Contemporary Islam in Indonesia.

Geri, M. (2019). Ethnic minorities in democratizing Muslim countries: Turkey and Indonesia. Palgrave Macmillan.

Giulianotti, R., \& Robertson, R. (2007). Forms of Glocalization: Globalization and the Migration Strategies of Scottish Football Fans in North America. Sociology, 41(1), $133-152$.

Hasan, N. (2009). Transnational Islam in Indonesia. In P. G. Mandaville (Ed.), Transnational Islam in South and Southeast Asia: Movements, Networks, and Conflict Dynamics. The National Bureau of Asian Research.

Kersten, C. (2018). A history of Islam in Indonesia.

Kosebalaban, H. (2011). Turkish foreign policy: Islam, nationalism, and globalization. Palgrave Macmillan.

Meuleman, J. (2005). Islam in the Era of Globalization: Muslim Attitudes towards Modernity and Identity.

Meuleman, J. H. (2002). Islam in the Era of Globalization Muslim Attitudes Towards Modernity and Identity. RoutledgeCurzon.

Mohammadi, A. (2002). Islam encountering globalization. RoutledgeCurzon.

OECD. (2018). PISA 2018.

Ozdalga, E. (1999). Naqshbandis in western and central Asia: change and continuity: papers read at a conference held at the Swedish Research Institute in Istanbul, June 911, 1997.

Parsons, D. (1997). The Music of Islam : recorded in Egypt, Morocco, Tunisia, Turkey, Yemen, Pakistan, Indonesia, Iran and Qatar. Celestial Harmonies.

Permana, F. E.. (2019, December 11). Kontak Ottoman Islam dan Nusantara, Ibnu Batutah: Hosmusam! Republika. https://www.republika.co.id/berita/duniaislam/khazanah/19/12/11/q2bia1320-kontak-ottoman-islam-dan-nusantara-ibnubatutah-hosmusam

Pringle, R. (2012). Understanding Islam in Indonesia: Politics and Diversity. Editions Didier Millet.

Robertson, R. (1995). Glocalization: Time-space and Homogeneity-heterogeneity. In M. Featherstone (Ed.), Global Modernities (pp. 25-44). Sage.

Roudometof, V. (2003). Glocalization, Space, and Modernity 1. The European Legacy: Toward New Paradigms, 8(1), 37-60.

Rudnyckyj, D. (2010). Spiritual economies: Islam, globalization, and the afterlife of development. Cornell University Press.

Rumadi, \& Lunnon, R. (2015). Islamic post-traditionalism in Indonesia.

Saat, N. (2018). The state, ulama and Islam in Malaysia and Indonesia.

Saleh, F. (2001). Modern trends in Islamic theological discourse in 20th century Indonesia: a critical study. Brill. 
Schneier, E. V. (2016). Muslim democracy: politics, religion and society in Indonesia, Turkey and the Islamic world. Routledge.

Setyaningrum, A. (2015). Pemikiran Pendidikan Asy-Syaukani dan Peranannya dalam Menciptakan Renaissance. Edukasia: Jurnal Penelitian Pendidikan Islam, 10.

Simandjuntak, D. (2018). No TitleIdentity politics looms over Indonesia's presidential election. https://www.eastasiaforum.org/2018/11/10/identity-politics-looms-overindonesias-presidential-election/

Turam, B. (2004). A bargain between the secular state and Turkish Islam: politics of ethnicity in Central Asia. NANA Nations and Nationalism, 10(3), 353-374.

Wahyudi, D. T. (2019, May 2). Toleransi Beragama Indonesia Menginspirasi Jerman. Indopos. https://indopos.co.id/read/2019/05/02/173913/toleransi-beragama-indonesiamenginspirasi-jerman/

Yavuz, M. H. (2003). Islamic Political Identity in Turkey. Oxford University Press.

Yilmaz, H. (2018). Comparison of the University Students in Turkey and Central Asia with Regards to Their Characteristics of Thinking, Decision Making and Cognitive Closure. Asian Journal of Education and Training, 4(4), 309-318. 
